\title{
KARAKTERISTIK PERTUMBUHAN JABON DARI PROVENAN SUMBAWA PADA TINGKAT SEMAI DAN SETELAH PENANAMAN
}

Growth Characteristic of Jabon from Sumbawa Provenance at Nursery and After Planting

\section{Tri Pamungkas Yudohartono}

\author{
Balai Besar Penelitian Bioteknologi dan Pemuliaan Tanaman Hutan \\ Jl. Palagan Tentara Pelajar Km. 15, Purwobinangun, Pakem, Sleman, Yogyakarta 55582 \\ e-mail : tyudohartono@yahoo.com.sg
}

\begin{abstract}
Growth is one of important and economic traits of jabon. Growth is not only determined by environment but also genetic factor. Seedling quality and suitable site would create well growing plants. This research is purposed to know growth characteristic of jabon from Sumbawa provenances in nursery and after plantation as well as the effect of genetic factor on growth characteristic of jabon. Research design used in nursery is Completely Randomized Design with 24 mother trees and 3 replications. Each replication comprises 10 seedlings. Totally, there are 720 seedlings. Experimental design used in progeny test plot of jabon is Randomized Complete Block Design. Breeding strategy used in this plot was subline system with single treeplot. Number of families used are 28 families. Each family comprises 20 blocks that were also functioned as replication. The results showed that there were significant differences in terms of height and diameter among the tested families at all observation ages. Family heritability estimates for height were high at at all observation ages. Family heritability estimates for diameter were high at nursery and moderate after plantation.
\end{abstract}

Keywords : jabon, characteristic, growth, nursery, provenance

\begin{abstract}
ABSTRAK
Pertumbuhan merupakan salah satu sifat tanaman jabon yang penting dan bernilai ekonomi. Pertumbuhan tidak hanya ditentukan oleh faktor lingkungan tetapi juga dipengaruhi faktor genetik. Tujuan penelitian ini adalah untuk mengetahui karakteristik/sifat pertumbuhan jabon dari provenan Sumbawa pada tingkat semai dan setelah penanaman serta mengetahui pengaruh faktor genetik terhadap karakteristik/sifat pertumbuhan jabon. Rancangan yang digunakan pada tingkat semai yaitu Rancangan Acak Lengkap dengan dengan 24 famili sebagai perlakuan, dengan 3 ulangan. Setiap ulangan terdiri dari 10 bibit sehingga jumlah bibit yang digunakan sebanyak 720 bibit. Rancangan percobaan yang digunakan dalam plot uji keturunan jabon adalah Rancangan Acak Lengkap Berblok. Strategi pemuliaan yang digunakan adalah sub galur dengan single treeplot. Jumlah famili yang digunakan adalah 28 famili. Setiap famili terdiri dari 20 blok yang sekaligus berfungsi sebagai ulangan. Hasil penelitian menunjukkan bahwa bahwa terdapat perbedaan yang nyata diantara famili yang diuji untuk sifat tinggi dan diameter pada semua umur pengamatan. Taksiran nilai heritabilitas famili untuk sifat tinggi pada tingkat semai dan setelah penanaman tergolong tinggi. Taksiran nilai heritabilitas famili untuk sifat diameter pada tingkat semai tergolong tinggi dan moderat setelah penanaman.
\end{abstract}

Kata kunci: Jabon, karakteristik, pertumbuhan, semai, provenan

Tanggal diterima : 31 Januari 2013 ; Direvisi : 14 Mei 2013; disetujui terbit :29 November 2013 


\section{PENDAHULUAN}

Tanaman jabon (Anthocephalus cadamba Miq) merupakan jenis tanaman cepat tumbuh, pemanfaatan kayunya sudah dikenal luas oleh masyarakat, dan teknik silvikulturnya telah diketahui. Jabon tergolong tumbuhan pionir. Jenis ini tersebar di seluruh Indonesia terutama di Sumatera, Kalimantan, Sulawesi, Maluku, Papua. Jenis ini juga ditemukan di Philipina, Papua New Guinea dan Kepulauan Solomon. Tumbuh di hutan hujan dataran rendah dan hutan sekunder atau tepi jalan logging. Pada distribusi alaminya, tanaman ini tumbuh baik pada ketinggian 0-1.000 $\mathrm{m}$ dpl dengan rata-rata curah hujan sekurang-kurangnya $1.500 \mathrm{~mm} /$ tahun atau wilayah beriklim basah hingga agak kering (tipe iklim A-C). Tumbuh di tanah alluvial atau tanah lembab di tepi sungai, dan tanah bertekstur liat atau liat berpasir (Soerianegara and Lemmens, 1994).

Kayu jabon dapat dipergunakan untuk korek api, peti pembungkus, cetakan beton, mainan anak-anak, pulp, kelom dan konstruksi darurat yang ringan. Kayu jabon juga dapat di gunakan sebagai bahan baku kertas (pulp) dikarenakan mempunyai sifat kimia yaitu memiliki kandungan selulosa cukup tinggi $\pm 52.4 \%$ dan panjang serat 1.979 (Martawijaya et al., 1992). Dalam pembangunan hutan tanaman, kualitas benih memainkan peranan yang sangat penting. Menurut Isik (1986); Singh et al (2006) dalam Singh and Bhatt (2008) biji yang dikumpulkan dari berbagai sumber yang berbeda akan berbeda dalam viabilitas, perkecambahan, pertumbuhan dan performa biomassa. Pertumbuhan tanaman yang baik di lapangan selain ditentukan oleh kualitas tapak yang sesuai dengan persyaratan tumbuh tanaman yang dibudidayakan juga dipengaruhi oleh baik buruknya kualitas bibit. Mutu/kualitas bibit merupakan ekspresi yang digunakan untuk menggambarkan kemampuan bibit untuk beradaptasi dan tumbuh setelah penanaman.

Balai Besar Penelitian Bioteknologi dan Pemuliaan Tanaman Hutan (BBPBPTH) Yogyakarta mulai tahun 2010 hingga 2012 telah membangun populasi dasar jabon. Materi genetik yang digunakan untuk pembangunan populasi dasar tersebut berasal dari empat provenan yaitu Ogan Ilir (Sumatera Selatan), Lombok Barat (Pulau Lombok), Pulau Sumbawa (Dompu dan Bima), dan Pasaman (Sumatera Barat). Populasi dasar jabon dirancang sebagai plot uji keturunan yang tidak akan dijarangi. Populasi dasar jabon didesain dengan menanam satu populasi pada satu blok atau setiap populasi terpisah dengan populasi lain. Hal ini dilakukan untuk mempertahankan identitas populasi yang disesuaikan kondisi setempatsertakarakteristikjenis tanamannya. Identitas populasi perlu dipertahankan agar dapat dilakukan karakterisasi dan evaluasi tanaman menurut asal geografisnya. Tujuan 
penelitian ini adalah untuk mengetahui:

1) karakteristik / sifat pertumbuhan jabon dari provenan Sumbawa pada tingkat semai (umur 5 dan 8 bulan di persemaian dan setelah 8 bulan penanaman), dan 2) pengaruh faktor genetik terhadap karakteristik/sifat pertumbuhan jabon.

\section{BAHAN DAN METODE}

\section{A. Waktu dan Tempat Penelitian}

Penelitian dilakukan di persemaian BBPBPTH dan plot uji keturunan jabon di Gunung Kidul. Famili-famili yang digunakan untuk pembangunan uji keturunan jabon berasal dari provenan Sumbawa. Pengukuran dan pengamatan karakteristik semai jabon di persemaian dilakukan pada umur 5 bulan (Juli 2012) dan 8 bulan (Oktober 2012). Karakterisasi tanaman plot uji keturunan jabon di Gunung Kidul dilakukan pada bulan Juli 2013 (umur 8 bulan). Plot uji keturunan jabon terletak di Petak 22, RPH Banaran, BDH Playen, Gunung Kidul. Secara administratif lokasi tersebut termasuk wilayah Desa Gading, Kecamatan Playen, Kabupaten Gunung Kidul. Plot tersebut mempunyai tipe iklim C dan Jenis tanah grumosol hitam/tanah berbatu. Kondisi areal memiliki kemiringan diantara 5 - 30\%. Topografinya sebagian landai hingga bergelombang, ketinggian berkisar 100 - $200 \mathrm{~m}$ dpl.

\section{B. Bahan dan Peralatan}

Bahan yang digunakan adalah semai jabon di persemaian dan tanaman jabon pada plot uji keturunan jabon. Informasi atau deskripsi setiap famili/famili yang digunakan dalam penelitian ini disajikan pada Tabel 1 (Yudohartono, in press). Bahan pendukung lain yang digunakan yaitu: media tabur, bak tabur, plastik sungkup, paranet, media sapih, dan polybag $20 \times 12$. Media sapih yang digunakan adalah tanah. Peralatan yang digunakan yaitu pinset, sprayer, digital caliper, penggaris, tally sheet dan alat-alat tulis.

\section{Metode Penelitian}

1. Rancangan penelitian

Rancangan yang digunakan untuk penelitian di persemaian adalah Rancangan Acak Lengkap (Completely Randomized Design) dengan 24 famili sebagai perlakuan, dengan 3 ulangan. Setiap ulangan terdiri dari 10 bibit sehingga jumlah bibit yang digunakan sebanyak 720 bibit. Rancangan percobaan yang digunakan dalam plot uji keturunan jabon adalah Rancangan Acak Lengkap Berblok (Randomized Complete Block Design). Desain yang digunakan untuk uji keturunan jabon adalah sub galur (subline system) dengan single treeplot. Jumlah famili yang digunakan adalah 28 famili. Setiap famili terdiri dari 20 blok yang sekaligus berfungsi sebagai ulangan. Jarak tanam yang digunakan pada plot uji keturunan jabon adalah 5 x $5 \mathrm{~m}$.

2. Karakteristik yang diamati

Karakteristik atau sifat yang diamati 
pada tingkat semai yaitu tinggi, dan diameter tinggi diukur mulai pangkal batang yang berbatasan dengan permukaan media sampai pucuk dan diameter diukur pada pangkal batang ( $\pm 1 \mathrm{~cm}$ dari leher akar). Karakteristik tanaman yang diamati pada plot populasi dasar jabon yaitu tinggi dan diameter. Tinggi tanaman diukur dari permukaan tanah sampai titik tumbuh apikal (ujung tanaman). Diameter batang diukur pada ketinggian 10 cm di atas permukaan tanah.

Tabel 1. Deskripsi famili yang digunakan dalam penelitian

\begin{tabular}{c|l|r|r|c|c|c|}
\hline No. & \multicolumn{1}{|c|}{ Lokasi } & \multicolumn{2}{|c|}{ Koordinat } & Elevasi & Diameter & Tinggi \\
\cline { 3 - 4 } Famili & (Administratif) & LS & BT & $(\mathrm{m} \mathrm{dpl})$ & $(\mathrm{cm})$ & $(\mathrm{m})$ \\
\hline 1 & Kab. Dompu & 8.46247 & 118.44664 & 285 & 48.7 & 12 \\
\hline 2 & Kab. Dompu & 8.43505 & 118.43632 & 400 & 143.3 & 25 \\
\hline 3 & Kab. Dompu & 8.43494 & 118.43609 & 401 & 58.9 & 14 \\
\hline 4 & Kab. Dompu & 8.43514 & 118.43651 & 393 & 156.1 & 25 \\
\hline 5 & Kab. Dompu & 8.43388 & 118.43532 & 427 & 101.9 & 18 \\
\hline 6 & Kab. Dompu & 8.43404 & 118.43533 & 375 & 136.9 & 29 \\
\hline 7 & Kab. Dompu & 8.43367 & 118.43651 & 375 & 149.7 & 25 \\
\hline 8 & Kab. Dompu & 8.43246 & 118.44671 & 217 & 157.6 & 28 \\
\hline 9 & Kab. Dompu & 8.44327 & 118.45386 & 251 & 133.8 & 26 \\
\hline 10 & Kab. Dompu & 8.44539 & 118.43477 & 251 & 98.7 & 31 \\
\hline 11 & Kab. Dompu & 8.45389 & 118.43476 & 253 & 94.0 & 29 \\
\hline 12 & Kab. Dompu & 8.45385 & 118.43478 & 251 & 79.6 & 14 \\
\hline 13 & Kab. Dompu & 8.45384 & 118.43484 & 253 & 103.5 & 25 \\
\hline 14 & Kab. Dompu & 8.45391 & 118.43479 & 215 & 130.6 & 34 \\
\hline 15 & Kab. Dompu & 8.45392 & 118.43491 & 252 & 97.1 & 30 \\
\hline 16 & Kab. Dompu & 8.45387 & 118.43482 & 251 & 66.9 & 36 \\
\hline 17 & Kab. Dompu & 8.45389 & 118.43484 & 252 & 44.6 & 29 \\
\hline 18 & Kab. Dompu & 8.45396 & 118.43481 & 250 & 58.9 & 32 \\
\hline 19 & Kab. Dompu & 8.45397 & 118.43487 & 252 & 46.2 & 28 \\
\hline 20 & Kab. Dompu & 8.45396 & 118.43485 & 253 & 47.8 & 27 \\
\hline 21 & Kab. Dompu & 8.45396 & 118.43487 & 254 & 65.3 & 33 \\
\hline 22 & Kab. Dompu & 8.45395 & 118.43491 & 254 & 57.3 & 21 \\
\hline 23 & Kab. Dompu & 8.45391 & 118.43494 & 255 & 94.0 & 30 \\
\hline 24 & Kab. Dompu & 8.45391 & 118.43495 & 253 & 58.9 & 26 \\
\hline 25 & Kab. Dompu & 8.45396 & 118.43493 & 254 & 54.1 & 24 \\
\hline 26 & Kab. Bima & 8.5966 & 118.58485 & 123 & 39.8 & 30 \\
\hline 27 & Kab. Bima & 8.59808 & 118.58529 & 121 & 121.0 & 40 \\
\hline 28 & Kab. Bima & 8.62508 & 118.6416 & 151 & 69.7 & 28 \\
\hline & & & & & & \\
\hline
\end{tabular}

\section{Analisis Data}

Data hasil pengukuran dianalisis dengan menggunakan analisis varian untuk mengetahui variasi antar famili-famili yang diuji. Apabila terdapat variasi antar famili yang diuji, maka dilanjutkan dengan Uji
Jarak Berganda Duncan (Duncan's Multiple Range Test-DMRT) untuk melihat perbedaan antar famili yang diuji. Model matematis yang digunakan dalam penelitian ini adalah sebagai berikut : 
1. Tingkat semai

$$
\mathbf{Y}_{\mathrm{ij}}=\boldsymbol{\mu}+\mathbf{P}_{\mathrm{i}}+\boldsymbol{\varepsilon}_{\mathrm{ij}}
$$

Keterangan :

$\mathrm{Y}_{\mathrm{ij}}=$ Karakteristik yang diamati/diukur

$\mu=$ Rerata umum

$\mathrm{P}_{\mathrm{i}}=$ Pengaruh famili ke- $\mathrm{i}$

$\varepsilon_{\mathrm{ij}}=$ Random error pada pengamatan ke-ij

2. Plot populasi dasar jabon (setelah penanaman)

$$
Y_{i j}=\mu+B_{i}+P_{j}+\varepsilon_{i j}
$$

Keterangan :

$\mathrm{Y}_{\mathrm{ij}}=$ Karakteristik yang diamati/diukur

$\mu=$ Rerata umum

$\mathrm{P}_{\mathrm{j}}=$ Pengaruh famili ke- $\mathrm{j}$

$\mathrm{B}_{\mathrm{i}}^{\mathrm{j}}=$ Pengaruh blok ke- $\mathrm{i}$

$\varepsilon_{\mathrm{ij}}=$ Random error pada pengamatan ke-ij

Heritabilitas ditaksir dengan menggunakan formula sebagai berikut (Hardiyanto, 2007) :

$$
h^{2}=\frac{\sigma_{f}^{2}}{\sigma_{f}^{2}+\left(\sigma_{b f}^{2}\right) / b+\left(\sigma_{e}^{2}\right) / n b}
$$

Keterangan :

$\mathrm{h}^{2} \quad=$ nilai heritabilitas famili

$\sigma^{2}{ }_{f}^{f} \quad=$ komponen varians famili

$\sigma^{2}{ }_{b f}=$ komponen varians interaksi blok dan famili

$\sigma_{\mathrm{e}}^{2} \quad=$ komponen varians error

$\mathrm{n} \quad=$ rerata harmonik jumlah pohon per plot

$\mathrm{b} \quad=$ rerata harmonik jumlah blok

\section{HASIL DAN PEMBAHASAN}

\section{A. Karakteristik Pertumbuhan \\ 1. Pada umur 5 dan 8 bulan di persemaian}

Untuk mengetahui variasi antar famili untuk sifat tinggi dan diameter maka dilakukan analisis varian terhadap data pengukuran tinggi diameter. Hasil analisis varian untuk sifat tinggi dan diameter disajikan pada Tabel 2.

Untuk melihat perbedaan dan ranking antar famili untuk variabel tinggi dilakukan pengujian lebih lanjut yaitu uji jarak berganda Duncan (DMRT) seperti disajikan

\begin{tabular}{|c|c|c|c|c|c|c|}
\hline Sifat & Umur & Sumber Variasi & Derajat bebas & Kuadrat Tengah & $\mathrm{F}$ & Sig. \\
\hline Tinggi & 5 bulan & $\begin{array}{c}\text { Famili } \\
\text { Error } \\
\text { Total }\end{array}$ & $\begin{array}{l}23 \\
48 \\
71\end{array}$ & $\begin{array}{l}239,310 \\
104,306\end{array}$ & $2,294 * *$ & 0,008 \\
\hline Tinggi & 8 bulan & $\begin{array}{c}\text { Famili } \\
\text { Error } \\
\text { Total }\end{array}$ & $\begin{array}{l}23 \\
48 \\
71\end{array}$ & $\begin{array}{l}228,299 \\
119,827\end{array}$ & $1,905^{*}$ & 0,030 \\
\hline Diameter & 5 bulan & $\begin{array}{c}\text { Famili } \\
\text { Error } \\
\text { Total }\end{array}$ & $\begin{array}{l}23 \\
48 \\
71\end{array}$ & $\begin{array}{l}1,407 \\
0,269\end{array}$ & $5,228 * *$ & 0,000 \\
\hline Diameter & 8 bulan & $\begin{array}{c}\text { Famili } \\
\text { Error } \\
\text { Total }\end{array}$ & $\begin{array}{l}23 \\
48 \\
71\end{array}$ & $\begin{array}{l}1,780 \\
0,345\end{array}$ & $5,158^{* *}$ & 0,000 \\
\hline & & & & & & \\
\hline
\end{tabular}
pada Tabel 3 dan 4 .

Tabel 2. Analisis varian untuk sifat tinggi dan diameter bibit jabon di persemaian pada umur 5 dan 8 bulan

Keterangan $* *=$ pengaruh nyata pada taraf uji $1 \%$

$*=$ pengaruh nyata pada taraf uji $5 \%$ 
Tabel 3. Uji jarak berganda Duncan untuk variabel tinggi umur 5 dan 8 bulan

\begin{tabular}{|c|c|c|c|c|c|}
\hline No & Famili & Tinggi 5 bulan $(\mathrm{cm})$ & No & Famili & Tinggi 8 bulan (cm) \\
\hline 1 & 9 & $33,83 \mathrm{f}$ & 1 & 10 & $44,65 \mathrm{~d}$ \\
\hline 2 & 10 & $35,62 \mathrm{ef}$ & 2 & 11 & $46,25 \mathrm{~d}$ \\
\hline 3 & 11 & $36,50 \mathrm{def}$ & 3 & 9 & $47,20 \mathrm{~d}$ \\
\hline 4 & 20 & $39,55 \mathrm{cdef}$ & 4 & 20 & $57,79 \mathrm{~cd}$ \\
\hline 5 & 12 & $41,42 \mathrm{cdef}$ & 5 & 5 & $53 \mathrm{bcd}$ \\
\hline 6 & 6 & $43,65 \mathrm{cdef}$ & 6 & 12 & $53,02 \mathrm{bcd}$ \\
\hline 7 & 5 & $44,80 \mathrm{bcdef}$ & 7 & 6 & $55,00 \mathrm{bcd}$ \\
\hline 8 & 17 & $45,03 \mathrm{bcdef}$ & 8 & 15 & $55,15 \mathrm{bcd}$ \\
\hline 9 & 15 & $45,57 \mathrm{bcdef}$ & 9 & 19 & $56,07 \mathrm{bcd}$ \\
\hline 10 & 8 & $46,25 \mathrm{bcdef}$ & 10 & 21 & $58,03 \mathrm{bcd}$ \\
\hline 11 & 16 & $48,27 \mathrm{bcdef}$ & 11 & 17 & $58,13 \mathrm{bcd}$ \\
\hline 12 & 13 & $48,33 \mathrm{bcdef}$ & 12 & 16 & $58,20 \mathrm{bcd}$ \\
\hline 13 & 19 & $49,25 \mathrm{bcdef}$ & 13 & 7 & $59,38 \mathrm{bcd}$ \\
\hline 14 & 7 & $49,65 \mathrm{bcdef}$ & 14 & 14 & $59,60 \mathrm{bcd}$ \\
\hline 15 & 14 & $50,48 \mathrm{bcdef}$ & 15 & 8 & $60,47 \mathrm{abcd}$ \\
\hline 16 & 24 & $52,53 \mathrm{abcdef}$ & 16 & 24 & $62,67 \mathrm{abcd}$ \\
\hline 17 & 21 & $54,07 \mathrm{abcdef}$ & 17 & 3 & $62,73 \mathrm{abcd}$ \\
\hline 18 & 1 & $54,367 \mathrm{abcde}$ & 18 & 13 & $62,87 \mathrm{abcd}$ \\
\hline 19 & 3 & $54,62 \mathrm{abcde}$ & 19 & 1 & $62,92 \mathrm{abcd}$ \\
\hline 20 & 4 & $56,23 \mathrm{abcd}$ & 20 & 4 & $64,37 \mathrm{abcd}$ \\
\hline 21 & 2 & $57,55 \mathrm{abc}$ & 21 & 2 & $66,55 \mathrm{abcd}$ \\
\hline 22 & 22 & $59,85 \mathrm{abc}$ & 22 & 22 & $69,22 \mathrm{abc}$ \\
\hline 23 & 18 & $64,50 \mathrm{ab}$ & 23 & 18 & $74,65 \mathrm{ab}$ \\
\hline 24 & 23 & $70,83 \mathrm{a}$ & 24 & 23 & $81,5 \mathrm{a}$ \\
\hline
\end{tabular}

Keterangan: Rata-rata yang dihubungkan dengan huruf yang sama, tidak berbeda pada taraf uji $5 \%$

Tabel 4. Uji jarak berganda Duncan untuk variabel diameter umur 5 dan 8 bulan

\begin{tabular}{|c|c|c|c|c|c|}
\hline No & Famili & Diameter 5 bulan $(\mathrm{mm})$ & No & Famili & Diameter 8 bulan (mm) \\
\hline 1 & 15 & $4,65 \mathrm{~h}$ & 1 & 10 & $6,05 \mathrm{i}$ \\
\hline 2 & 8 & $4,91 \mathrm{gh}$ & 2 & 4 & $6,15 \mathrm{i}$ \\
\hline 3 & 9 & 4,96 fgh & 3 & 15 & $6,24 \mathrm{hi}$ \\
\hline 4 & 11 & $5,06 \mathrm{efgh}$ & 4 & 16 & $6,32 \mathrm{hi}$ \\
\hline 5 & 10 & $5,09 \mathrm{efgh}$ & 5 & 11 & $6,38 \mathrm{hi}$ \\
\hline 6 & 14 & $5,10 \mathrm{efgh}$ & 6 & 3 & 6,5 ghi \\
\hline 7 & 4 & $5,14 \mathrm{efgh}$ & 7 & 14 & $6,55 \mathrm{ghi}$ \\
\hline 8 & 17 & $5,19 \mathrm{efgh}$ & 8 & 5 & 6,67 fghi \\
\hline 9 & 16 & $5,19 \mathrm{efgh}$ & 9 & 24 & 6,72 fghi \\
\hline 10 & 3 & $5,22 \mathrm{efgh}$ & 10 & 6 & $6,76 \mathrm{efghi}$ \\
\hline 11 & 6 & $5,23 \mathrm{efgh}$ & 11 & 22 & $6,79 \mathrm{efghi}$ \\
\hline 12 & 20 & $5,29 \mathrm{efgh}$ & 12 & 8 & $6,84 \mathrm{efghi}$ \\
\hline 13 & 5 & $5,34 \mathrm{efgh}$ & 13 & 9 & $6,91 \mathrm{defghi}$ \\
\hline 14 & 24 & $5,37 \mathrm{efgh}$ & 14 & 12 & $7,11 \mathrm{defghi}$ \\
\hline 15 & 12 & $5,39 \mathrm{efgh}$ & 15 & 13 & $7,39 \mathrm{bcdefgh}$ \\
\hline 16 & 22 & $5,50 \mathrm{defgh}$ & 16 & 20 & $7,56 \mathrm{bcdefg}$ \\
\hline 17 & 13 & $5,63 \mathrm{defgh}$ & 17 & 17 & $7,59 \mathrm{bcdefg}$ \\
\hline 18 & 1 & $5,77 \mathrm{cdefg}$ & 18 & 19 & $7,81 \mathrm{abcdef}$ \\
\hline 19 & 7 & $5,98 \mathrm{bcdef}$ & 19 & 1 & $7,90 \mathrm{abcde}$ \\
\hline 20 & 2 & $6,09 \mathrm{bcde}$ & 20 & 2 & $7,99 \mathrm{abcd}$ \\
\hline 21 & 19 & $6,38 \mathrm{bcd}$ & 21 & 7 & $8,11 \mathrm{abc}$ \\
\hline 22 & 18 & $6,71 \mathrm{abc}$ & 22 & 21 & $8,42 \mathrm{ab}$ \\
\hline 23 & 21 & $6,82 \mathrm{ab}$ & 23 & 18 & 23 \\
\hline 24 & 23 & $7,44 \mathrm{a}$ & 24 & 23 & \\
\hline
\end{tabular}

Keterangan: Rata-rata yang dihubungkan dengan huruf yang sama, tidak berbeda pada taraf uji $5 \%$ 


\section{Tinggi dan diameter pada 8 bulan setelah penanaman}

Untuk mengetahui variasi antar famili untuk sifat tinggi dan diameter jabon pada 8 bulan setelah penanaman maka dilakukan analisis varian terhadap data pengukuran tinggi. Hasil analisis varian untuk sifat tinggi

Tabel 5. Analisis varian untuk sifat tinggi dan diameter bibit jabon pada 8 bulan setelah penanaman

\begin{tabular}{|l|c|c|c|c|}
\hline Sumber Variasi & Derajat bebas & Kuadrat Tengah & F & Sig. \\
\hline \multicolumn{5}{|c|}{ Tinggi } \\
\hline Famili & 27 & 3821,922 & $1,769^{*}$ & 0,011 \\
Blok & 19 & 19825,848 & $9,176^{* *}$ & 0,000 \\
Error & 412 & 2160,510 & & \\
\hline Famili & 27 & 133,841 & $1,592^{*}$ & 0,032 \\
Blok & 19 & 797,725 & $9,487^{* *}$ & 0,000 \\
Error & 412 & 84,083 & & \\
\hline
\end{tabular}

Keterangan $* *=$ pengaruh nyata pada taraf uji $1 \%$

$*$ = pengaruh nyata pada taraf uji $5 \%$

Tabel 6. Uji jarak berganda Duncan untuk sifat tinggi pada umur 8 bulan setelah penanaman

\begin{tabular}{|c|c|c|c|c|c|}
\hline No & Famili & Tinggi 8 bulan $(\mathrm{cm})$ & No & Famili & Tinggi 8 bulan $(\mathrm{cm})$ \\
\hline 1 & 13 & $80,63 \mathrm{~d}$ & 15 & 28 & $101,79 \mathrm{bcd}$ \\
\hline 2 & 15 & $81,05 \mathrm{~d}$ & 16 & 25 & $102,82 \mathrm{bcd}$ \\
\hline 3 & 9 & $85,15 \mathrm{~cd}$ & 17 & 20 & $103,64 \mathrm{bcd}$ \\
\hline 4 & 12 & $86,00 \mathrm{bcd}$ & 18 & 6 & $104,87 \mathrm{bcd}$ \\
\hline 5 & 7 & $86,06 \mathrm{bcd}$ & 19 & 8 & $105,21 \mathrm{bcd}$ \\
\hline 6 & 27 & $88,89 \mathrm{bcd}$ & 20 & 3 & $107,00 \mathrm{bcd}$ \\
\hline 7 & 24 & $90,00 \mathrm{bcd}$ & 21 & 17 & $110,57 \mathrm{abcd}$ \\
\hline 8 & 5 & $90,67 \mathrm{bcd}$ & 22 & 14 & $113,63 \mathrm{abcd}$ \\
\hline 9 & 21 & $92,11 \mathrm{bcd}$ & 23 & 1 & $115,47 \mathrm{abcd}$ \\
\hline 10 & 23 & $93,13 \mathrm{bcd}$ & 24 & 22 & $117,86 \mathrm{abcd}$ \\
\hline 11 & 18 & $95,25 \mathrm{bcd}$ & 25 & 16 & $122,00 \mathrm{abc}$ \\
\hline 12 & 4 & $98,92 \mathrm{bcd}$ & 26 & 11 & $123,18 \mathrm{abc}$ \\
\hline 13 & 26 & $100,94 \mathrm{bcd}$ & 27 & 19 & $126,63 \mathrm{ab}$ \\
\hline 14 & 10 & $101,33 \mathrm{bcd}$ & 28 & 2 & $145,11 \mathrm{a}$ \\
\hline
\end{tabular}

Keterangan: Rata-rata yang dihubungkan dengan huruf yang sama, tidak berbeda pada taraf uji 5\% disajikan pada Tabel 5.

Untuk melihat perbedaan dan ranking antar famili untuk variabel tinggi dan diameter dilakukan pengujian lebih lanjut yaitu uji jarak berganda Duncan (DMRT) seperti disajikan pada Tabel 6 dan 7. 
Tabel 7. Uji jarak berganda Duncan untuk sifat diameter pada umur 8 bulan setelah penanaman

\begin{tabular}{|c|c|c|c|c|c|}
\hline No & Famili & Diameter 8 bulan $(\mathrm{mm})$ & No & Famili & Diameter 8 bulan $(\mathrm{mm})$ \\
\hline 1 & 12 & $14,77 \mathrm{~b}$ & 15 & 5 & $19,51 \mathrm{ab}$ \\
\hline 2 & 15 & $14,87 \mathrm{~b}$ & 16 & 28 & $19,67 \mathrm{ab}$ \\
\hline 3 & 21 & $15,77 \mathrm{~b}$ & 17 & 17 & $20,08 \mathrm{ab}$ \\
\hline 4 & 9 & $16,16 \mathrm{~b}$ & 18 & 14 & $20,13 \mathrm{ab}$ \\
\hline 5 & 18 & $16,22 \mathrm{~b}$ & 19 & 4 & $20,23 \mathrm{ab}$ \\
\hline 6 & 13 & $16,24 \mathrm{~b}$ & 20 & 8 & $20,63 \mathrm{ab}$ \\
\hline 7 & 7 & $16,39 \mathrm{~b}$ & 21 & 16 & $21,27 \mathrm{ab}$ \\
\hline 8 & 24 & $16,46 \mathrm{~b}$ & 22 & 23 & $21,62 \mathrm{ab}$ \\
\hline 9 & 6 & $17,14 \mathrm{~b}$ & 23 & 25 & $22,15 \mathrm{ab}$ \\
\hline 10 & 27 & $18,11 \mathrm{ab}$ & 24 & 22 & $22,65 \mathrm{ab}$ \\
\hline 11 & 3 & $18,64 \mathrm{ab}$ & 25 & 1 & $22,67 \mathrm{ab}$ \\
\hline 12 & 10 & $19,42 \mathrm{ab}$ & 26 & 19 & $22,76 \mathrm{ab}$ \\
\hline 13 & 11 & $19,46 \mathrm{ab}$ & 27 & 26 & $22,82 \mathrm{ab}$ \\
\hline 14 & 20 & $19,50 \mathrm{ab}$ & 28 & 2 & $25,19 \mathrm{a}$ \\
\hline
\end{tabular}

Keterangan: Rata-rata yang dihubungkan dengan huruf yang sama, tidak berbeda pada taraf uji $5 \%$

Dari Tabel 2 dan 5 diketahui bahwa terdapat perbedaan yang nyata diantara famili yang diuji untuk sifat tinggi dan diameter pada semua umur pengamatan. Perbedaan tersebut menunjukkan bahwa famili memberikan pengaruh terhadap karakterisitik tinggi dan diameter pada semua umur pengamatan (5 dan 8 bulan pada tingkat semai maupun setelah 8 bulan penanaman). Variasi sifat tinggi, dan diameter semai jabon dari berbagai famili provenan Sumbawa diduga disebabkan oleh perbedaan kondisi tempat tumbuh antar famili yang bervariasi. Menurut Zobel, et al (1960b), variasi tanaman hutan dapat terjadi antar spesies, provenan, tegakan, tempat tumbuh, individu pohon dan variasi dalam individu pohon. Variasi geografis (provenan) merupakan faktor yang paling penting atau berperan terhadap karakteristik tanaman hutan yang terkait dengan kemampuan bertahan hidup dan adaptabilitas. Sementara itu, karakteristik ekonomi tanaman yang tidak berhubungan dengan fitness seperti kelurusan batang dan pertumbuhan paling banyak dipengaruhi variasi individu pohon (antar pohon). Ismail, et al., (1995) juga meneliti variasi karakteristik anatomi jabon dengan hasil penelitian yang menunjukkan perbedaan yang nyata pada variasi anatomi antar pohon. Kegiatan konservasi sumberdaya genetik dan pemuliaan tidak bisa terlepas dari variasi genetik yang merupakan sumberdaya yang bisa dimanfaatkan untuk generasi sekarang dan di masa yang akan datang. Menurut Palmberg-Lerche dalam Na'iem (2001), konservasi sumberdaya genetik adalah upaya pengelolaan sumberdaya genetik sedemikian rupa sehingga didapatkan 
produktivitas tertinggi secara lestari untuk keperluan generasi saat ini, sementara potensi ini tetap dipertahankan sedemikian rupa sehingga bermanfaat untuk kepentingan generasi mendatang. Dengan adanya variasi pertumbuhan atau keragaman genetik tinggi yang terdapat antar famili di dalam provenan Sumbawa maka semakin banyak potensi sumberdaya genetik tanaman jabon yang bisa dipertahankan atau diselamatkan. Disamping itu keragaman genetik yang tinggi juga sangat penting dalam program pemuliaan jabon karena optimalisasi perolehan genetik akan dapat dicapai dengan semakin besarnya peluang untuk seleksi terhadap sifat-sifat yang diinginkan.

Dari hasil uji Duncan untuk semai jabon umur 5 dan 8 bulan diketahui bahwa ranking famili untuk sifat tinggi dan diameter belum menunjukkan konsistensi. Pada sifat tinggi, ada kecenderungan beberapa famili mengelompok pada ranking yang relatif sama pada umur pengamatan 5 dan 8 bulan. Famili 9, 10,11 dan 20 mengelompok pada ranking terendah baik pada umur 5 dan 8 bulan. Famili 2, 4, 18, 22 dan 23 mengelompok pada ranking tertinggi pada umur pengamatan 5 dan 8 bulan. Bahkan pada umur 5 dan 8 bulan, urutan ranking untuk kelompok famili dengan nilai tertinggi adalah sama yaitu 4, 2, 18, 22 dan 23. Pada sifat diameter, ada kecenderungan famili 2 , 18, 21 dan 23 mengelompok pada ranking tertinggi pada umur pengamatan 5 dan 8 bulan. Famili 10, 11 dan 15 mengelompok pada ranking terendah baik pada umur 5 dan 8 bulan. Pada umur 8 bulan setelah penanaman, hasil uji berjarak Duncan menunjukkan bahwa ada kecenderungan beberapa famili juga mengelompok pada ranking yang relatif sama untuk sifat tinggi dan diameter. Famili 2, 19, dan 22 mengelompok pada ranking tertinggi dan famili 9, 12 dan 15 mengelompok pada ranking terendah. Famili 2 dan 22 termasuk dalam 5 famili terbaik untuk sifat tinggi pada semua umur pengamatan. Sedangkan untuk sifat diameter, hanya famili 2 yang dalam 5 famili terbaik pada semua umur pengamatan. Informasi variasi sifat pertumbuhan tinggi dan diameter tersebut sangat penting bagi program pemuliaan jabon terutama untuk proses seleksi.

\section{Nilai heritabilitas}

Hasil perhitungan menunjukkan bahwa taksiran nilai heritabilitas famili $\left(\mathrm{h}_{\mathrm{f}}^{2}\right)$ sifat tinggi untuk semai jabon umur 5 bulan, semai jabon umur 8 bulan dan tanaman jabon setelah 8 bulan penanaman masing-masing adalah 0,$95 ; 0,94$ dan 0,83 . Taksiran nilai heritabilitas famili $\left(\mathrm{h}_{\mathrm{f}}^{2}\right)$ sifat diameter untuk semai jabon umur 5 bulan, semai jabon umur 8 bulan dan tanaman jabon setelah 8 bulan penanaman masing-masing adalah 0,84 ; 0,81 dan 0,41. Leksono (1994) menyatakan bahwa heritabilitas famili $\left(\mathrm{h}_{\mathrm{f}}^{2}\right)$ dibawah 0,40 tergolong rendah; 0,40-0,60 dikategorikan 
menengah dan lebih dari 0,60 dianggap tinggi. Nilai heritabilitas famili yang tinggi dan sedang mengindikasikan bahwa faktor genetik memberikan pengaruh yang cukup kuat terhadap variasi sifat pertumbuhan tinggi dan diameter. Informasi mengenai nilai heritabilitas akan membantu proses seleksi dalam program pemuliaan pohon (Wright, 1976). Nilai heritabilitas famili sifat tinggi dan diameter semakin kecil dengan bertambahnya umur tanaman jabon. Nilai heritabilitas pada tanaman umumnya akan selalu berubah atau berbeda menurut waktu (umur tanaman), tempat dan jenis (Zobel dan Talbert, 1984). Hasil penelitian Ismail dan Yayan (2008) menunjukkan bahwa taksiran nilai heritabilitas famili untuk sifat diameter pada uji keturunan sengon umur 8 bulan di Kabupaten Kediri, Jawa Timur adalah 0,44. Susanto (1999) melaporkan bahwa heritabilitas famili untuk sifat diameter di KBSUK sengon di Candiroto, Jawa Tengah pada umur 3 tahun adalah 0,68. Heritabilitas famili untuk sifat tinggi dan diameter di kombinasi uji provenan dan uji keturunan araucaria di Bondowoso pada umur 18 bulan masing-masing adalah 0,42 dan 0,57 (Setiadi, 2010). Heritabilitas famili untuk sifat tinggi dan diameter di kombinasi uji provenan dan uji keturunan araucaria di Bondowoso pada umur 5 tahun masing-masing adalah 0,49 dan 0,72 (Setiadi dan Susanto, 2012).

\section{KESIMPULAN}

1. Variasi karakteristik/sifat tinggi diantara famili yang diuji menunjukkan perbedaan yang nyata pada umur 5 bulan di persemaian 8 bulan di persemaian dan umur 8 bulan setelah penanaman. Perbedaan tersebut menunjukkan bahwa famili memberikan pengaruh terhadap sifat pertumbuhan tinggi dan diameter pada semua umur pengamatan.

2. Taksiran nilai heritabilitas famili untuk sifat tinggi pada tingkat semai dan setelah penanaman tergolong tinggi. Taksiran nilai heritabilitas famili untuk sifat diameter pada tingkat semai tergolong tinggi. Taksiran nilai heritabilitas famili untuk sifat diameter setelah penanaman tergolong moderat. Nilai ini mengindikasikan bahwa pertumbuhan tinggi dan diameter pada tingkat semai dan setelah penanaman cukup kuat dikendalikan oleh faktor genetik. Bibit yang memiliki sifat pertumbuhan diameter, dan tinggi, yang relatif tertinggi pada semua umur pengamatan berasal dari famili yang sama yaitu 23. Bibit yang memiliki nilai rata-rata terendah untuk sifat pertumbuhan diameter pada umur pengamatan 5 dan 8 bulan masingmasing berasal dari famili 15 dan 10 . Untuk sifat tinggi, bibit yang memiliki nilai rata-rata terendah pada semua umur pengamatan 5 dan 8 bulan masingmasing adalah famili 9 dan 10 . 


\section{UCAPAN TERIMA KASIH}

Penulis mengucapkan terima kasih kepada semua pihak yang membantu kelancaran penelitian ini, khususnya kepada Rizki Ary Fambayun, S.Hut, Priska Rini Herdiyanti, S.Hut dan Diro Eko Pramono, S.Hut.T yang telah membantu dalam kegiatan penyiapan, pengukuran tanaman, dan entry data.

\section{DAFTAR PUSTAKA}

Ismail, J., M.Z. Jusoh and M.H. Sahri. 1995. Anatomical Variation in Planted Kelempayan (Neolamarckia cadamba, Rubiaceae). IAWA Journal. 16(3): 277287

Ismail, B dan Yayan, H. 2008. Evaluasi awal uji keturunan sengon (Paraserianthes falcataria) umur 8 bulan di Kabupaten Kediri, Jawa Timur. Jurnal Pemuliaan Tanaman Hutan Vol. 2 No. 3, November 2008. Balai Besar Penelitian Bioteknologi dan Pemuliaan Tanaman Hutan. Badan Penelitian dan Pengembangan Kehutanan, Departemen Kehutanan.

Leksono, B. 1994. Variasi genetik produksi getah Pinus merkusii Jungh. Et. De Vriese. Thesis (S2) Program Studi Ilmu Kehutanan, Jurusan Ilmu-ilmu Pertanian. Fakultas Pasca Sarjana UGM (Tidak Dipublikasikan).

Martawijaya, A., Kartasujana, I., Mandang,Y.I, Prawira, S.A., dan Kadir, K. 1992. Habitus Atlas kayu Indonesia Jilid II. Badan Litbang. Bogor.

Na'iem, M, 2001. Konsevasi Sumberdaya Genetik untuk Pemuliaan Pohon. Seminar Sehari 70 Tahun Prof. Oemi H. Suseno; Peletakan Dasar-dasar dan Strategi Pemuliaan Pohon Hutan di Indonesia. Yogyakarta.

Setiadi, D. 2010. Keragaman genetik uji provenans dan uji keturunan Araucaria cunninghamii umur 18 bulan di Bondowoso Jawa Timur. Jurnal Pemuliaan Tanaman Hutan Vol. 4 No. 1, Juli 2010. Balai Besar Penelitian Bioteknologi dan Pemuliaan Tanaman Hutan. Badan Penelitian dan Pengembangan Kehutanan, Departemen Kehutanan.

Setiadi, D dan Muji, S. 2012. Variasi genetik pada kombinasi uji provenans dan uji keturunan Araucaria cunninghamii di Bondowoso Jawa Timur. Jurnal Pemuliaan Tanaman Hutan Volume 6 No. 3, November 2012. Balai Besar Penelitian Bioteknologi dan Pemuliaan Tanaman Hutan. Badan Penelitian dan Pengembangan Kehutanan, Departemen Kehutanan.

Singh, B and B.P. Bhatt. 2008. Provenance Variation in Pod, Seed, and Seedling Traits of Dalbergia sissoo Roxb, Central Himalaya, India. Tropical Agricultural Research and Extension. 11: 39-44

Soerianegara, I and R.H.M.J. Lemmens. 1994. Timber Trees : Major Commercial Timber. PROSEA. Bogor.

Susanto, M. 1999. Evaluasi awal kebun benih uji keturunan jenis Paraserianthes falcataria umur 3 tahun di Candiroto Jawa Tengah. Buletin Penelitian Pemuliaan Pohon Vol. 3 No. 1. Balai Penelitian dan Pengembangan Pemuliaan dan Bioteknologi Tanaman Hutan. Badan Penelitian dan Pengembangan Kehutanan, Departemen Kehutanan.

Wright, J.W. 1976. Introduction to forest genetic. Academic Press, New York.

Zobel, B.J., Thurbjorsen, E. And Henson, F. 1960b. Geographic site and individual tree variation in wood properties of loblolly pine. Sil.Gen. 9(6) : 149-158

Zobel, B. J and J. Talbert. 1984. Applied Forest Tree Improvement. John Wiley and Sons, Inc., New York. 
Jurnal Pemuliaan Tanaman Hutan

Vol 7 No. 2, September 2013, 85 - 96 